\title{
YURI VELLA ON THE MOVE: DRIVING AN UAZIK IN WESTERN SIBERIA
}

\author{
Liivo Niglas
}

\begin{abstract}
In this paper, I want to demonstrate how modern technology can be employed in the sustainability strategy of an indigenous person who is trying to hold on to a traditional mode of existence. In the case of Yuri Vella, who is the main research subject of this study, modern technology is not only used for carrying out everyday domestic and economic activities. For him it is also a tool to withstand corporate pressure on traditional sources of livelihood. Yuri Vella has incorporated a wide range of modern technological devices into his forest universe. I will argue that one of the most crucial technological items he is relying on in his daily struggle for economic, cultural and political survival is a car. Paradoxically, the extraction of oil that is needed to sustain his "automobility", is a principal factor that is threatening his indigenous way of life in this oil-rich region of Western Siberia.
\end{abstract}

Key words: anthropological film, automobility, nomadism, reindeer herding, technological change, visual anthropology

\section{INTRODUCTION}

Yuri Vella lives in the basin of the Agan River. It is situated in the Mid-Ob region of the Western Siberian Plain, which is poorly drained and consists of some of the world's largest swamps and floodplains. A unique combination of harsh climatic conditions, an abundance of natural resources, an extremely vulnerable environment, a modest infrastructure and a multi-ethnic population characterize this region. The local indigenous people, the Khanty and the Forest Nenets, adapted to this severe natural habitat by developing a way of life that was based on hunting, fishing and reindeer herding. Since the 1960s, when oil was discovered in the region, these traditional subsistence activities came under pressure because the oil-industry competes for the same resource - the land - that the natives living in the forest need for their survival. The state authorities have always sided with the oil producers in this conflict because the Russian national budget relies heavily on oil revenue.

Yuri Vella is one of those natives who are holding on to their land. So far he has been successful in his struggle to maintain a traditional way of life despite 
the economic, political and psychological constraints that come with being in constant conflict with the powerful oil-industry. It surely requires a lot of courage and determination, but in Yuri Vella's case it can be also explained by his unique way of thinking about and reacting to the challenges of everyday reality. Unlike many other indigenous people in Northern Siberia, Yuri Vella has over the years been able to integrate into his mental world aspects of different realities and value systems that are often in conflict with each other. ${ }^{1}$

As a member of a small ethnic group of 2000 people, the Forest Nenets, Yuri Vella inherited a worldview based on nomadic reindeer herding and traditional folk stories. On the other hand, he grew up and studied in a typical national village, which was formed as a result of the official settlement policy with the aim of turning the "backward natives" into proper Soviet citizens. Since his early youth, he has been writing poems and stories in order to quench his thirst to express his understanding of the world, and in his thirties he studied by correspondence at the Poetry Department of the Moscow Institute of Literature while working as a hunter. After the collapse of the Soviet economy, he bought some reindeers and moved with his family to live in the forest. $\mathrm{He}$ had to become politically active and to learn to fight for his indigenous and property rights in order to survive as a reindeer herder in one of the most important oil-producing regions of Russia. From these different life experiences Yuri Vella has constructed himself a worldview that helps him to face the harsh reality of an indigenous person in Western Siberia (Niglas \& Toulouze 2004).

Mental strength is crucial for survival in a severe physical and social environment but it has to be supported by adequate technology, if it is to be sustainable. Yuri Vella has created in his forest home a technological environment, which offers him and his family a traditional way of life with modern comforts. One of the most important technological tools in his material world is a car.

Yuri Vella obtained his first car ${ }^{2}$ about 10 years ago, since then he has had three cars. It has always been the same model - UAZ $452^{3}$ This four-wheel drive minibus (there is also a pickup-truck model) is a simple, rather uncomfortable car that is strong and capable of driving on almost any terrain. The UAZ 452 has been manufactured without major changes since 1966 and was for a long time mostly reserved for the police, army and paramedic use. The minibus and other UAZ cars, most notably the UAZ 469, which was very similar in design to the original Jeep, have gained legendary status in Russia. People inhabiting regions with modest infrastructure and difficult road conditions use these vehicles still to this day due to their off-road ability, reliability and simplicity. The popular name for these cars is uazik and they are a good 
alternative to the more expensive Western made 4x4's. Apart from the lower cost, the popularity of uazik cars lies in their much simpler design compared to sophisticated, "computerized" Western off-road vehicles.

For Yuri Vella, the uazik is the best choice for a car as it is easy to use and maintain in the field conditions of Western Siberia. And, as I will show in this paper, the uazik is a suitable car for carrying out various tasks in Yuri Vella's everyday life: it helps him to take care of his reindeer; it makes it possible to maintain vital links with his native village and with bigger towns in the region, and it serves also as an effective tool for defending his indigenous rights.

Many indigenous people use cars in Western Siberia, but in this paper I have chosen to focus on a single individual rather than on an ethnic group or entire region. I feel that it allows to get deeper into the phenomenon's complexity without having to generalise on a significant amount of individual diversity. My emphasis is on "personal culture" rather than on "collective culture" (as in Valsiner 2007) because Yuri Vella is a man, whose idiosyncratic semiotic-system of symbols, practices and personal objects differs substantially from the communally shared meanings, social norms and everyday life practices of the indigenous people of the region. There is also a methodological reason why I prefer to narrow my research focus to a single person.

For me, fieldwork is mainly a visual experience. Therefore, I usually use a video camera as a means to pursue ethnographic enquiry, and an anthropological documentary film as a way to present research results. Filmmaking, much like classical ethnographic fieldwork, is always specific, rooted in a certain time and place, and focused on particular individuals. But unlike written ethnography, the recorded images cannot produce explicit statements about collective culture. Any generalizations, which can be found in a film, ${ }^{4}$ are there implicitly, evoked by the images of specific individuals in a specific environment, and by the way of presenting those images in a film narrative. Similarly to a film, this paper contains very few general statements. The empirical data presented here about one individual's personal use of a car could be used as raw material for a generalization on the collective car culture of the indigenous people of Western Siberia. But I hope the paper also offers something else.

When visiting Yuri Vella, my primary goal has always been filmmaking rather than doing classical ethnographic research. Therefore, this paper should be read as the work of an anthropological filmmaker who is trying to conceptualize an interesting cultural phenomenon encountered while recording the life of a particular person. Thus, the findings presented here are not the result of a pre-planned and in-depth ethnographic enquiry; they are more like a sideproduct of other work - ideas gained during shooting and editing footage about a very specific indigenous man. 
I have been trying to record and understand Yuri Vella's world with the help of a video camera since 2000, when I first set out to film his life in the forests of Western Siberia. Since then I have been to his place four times, spending there altogether three months and recording about 60 hours of footage. The first two fieldtrips resulted in a $58 \mathrm{~min}$ anthropological film Yuri Vella's World (2003) and the footage captured during the last two trips ${ }^{5}$ will soon be edited into a new feature-length documentary about this remarkable man. Therefore, I am compelled to consider (at least to a certain extent) the requirements of a narrative film in my choices during video shooting, both in choosing the episodes to be filmed and in actual camera work. But as an anthropologist I try to film in the way that offers viewers not only an audiovisual representation of the observed reality but also some anthropological knowledge of this reality. By filming Yuri Vella, I have attempted to bring withinreach the social experience of one particular individual. Besides the intellectual side of this experience, I was also interested in something else. Much of it can be put under the heading of "sensory knowledge" - that is "how people perceive their material environment and interact with it, both its natural and cultural forms, including their interaction with others as physical beings" (MacDougall 2005: 268).

In order to gain a deeper anthropological knowledge of what it means for Yuri Vella to drive a car in Western Siberia, it would be fruitful to use video material as a sort of catalyst that could provide the mechanism of understanding his sensory experience of driving the car. Unfortunately it is not possible to include actual video material in a written text. Therefore, for this presentation the video footage serves mainly as a set of fieldwork notes, which helps me to reflect on the economic, social and political aspects of Yuri Vella's personal usage of a car. The emotional, sensory and reflective dimension of the recorded material will be dealt with only to certain extent.

\section{YURI VELLA AND MOBILITY}

It has always been very intense to film Yuri Vella. It requires a great deal of stamina from a filmmaker to keep up with him, because he is constantly on the move, both physically and mentally.

When talking to Yuri one quickly notices that his mind is seldom in the present; that he mostly talks about the future. Almost everything he does, be it taking care of his reindeers, making a new sledge or dealing with his grand children, is directed towards a distant tomorrow, his thoughts are traveling always into a future 50 or 70 years from now (Niglas \& Toulouze 2004). 
But he moves a great deal in the physical world as well. He travels often away from his tribal territory (in Russian: rodovoie ugodie) in order to give a talk in a local school or to participate in a TV talk show or to work on a new book with an illustrator in one of the regional cities (Surgut, Nizhnevartovsk, Khanty-Mansiysk). Quite often he has to take a plane to Moscow or to other regions in Russia for a meeting or lecture. Sometimes he travels to Europe or to North America to represent Native Siberians in human and indigenous rights events. And in order to lead the life of a reindeer herder he has to move around in his proper territory a lot: it takes lots of comings and goings to look after ones reindeer, to travel between different camps and to get to a good hunting ground or fishing place.

Yuri Vella's open, slightly restless, nature is manifested through his eagerness to adopt new things into his world. He is always ready to try out a new machine, a new technology. It is very comfortable to stay at his forest camps, compared to many other indigenous households in the area. The houses at his camps are built according to the traditional Khanty model - one-room log buildings with an iron stove in the corner - but the presence of the contemporary world is manifested in technological details. Yuri has an electric generator that allows him and his family to use modern technology to make life easier in the forest conditions. There is an electric stove in the winter house that enables his wife to bake bread without working outside in the cold. There is usually a TV set in the house, regardless of which seasonal camp he and his family are staying in: Yuri has a large collection of videotapes, which consist of both fiction and documentary films that he likes to watch before going to sleep, as well as the footage he has filmed himself with a video camera to document indigenous reality in the changing physical and social environment. For more than a decade Yuri has had a computer that he uses to write poems, design his books and watch DVDs. He keeps in contact with the outside world through a mobile phone that he was relying on a long time before "the mobile phone revolution" kicked off in Western Siberia (Stammler 2009: 61) ${ }^{6}$. In spring 2009, a permanent Internet connection was established in his winter camp through a satellite dish with the help of UNESCO. Yuri also owns a set of modern tools, which help him to conduct his day-to-day tasks in the camp: a chainsaw, a portable sawmill and various electric tools.

As reindeer herding, fishing and hunting requires a lot of moving around, Yuri tries to use modern technology for transport whenever possible. He has a motorboat for collecting fish from traps or taking his wife and daughter(s) for berry picking in summer. In order to have the access to a larger fishing area, he and his grandsons dug numerous channels that connect eleven lakes into a man-made system of waterways. 


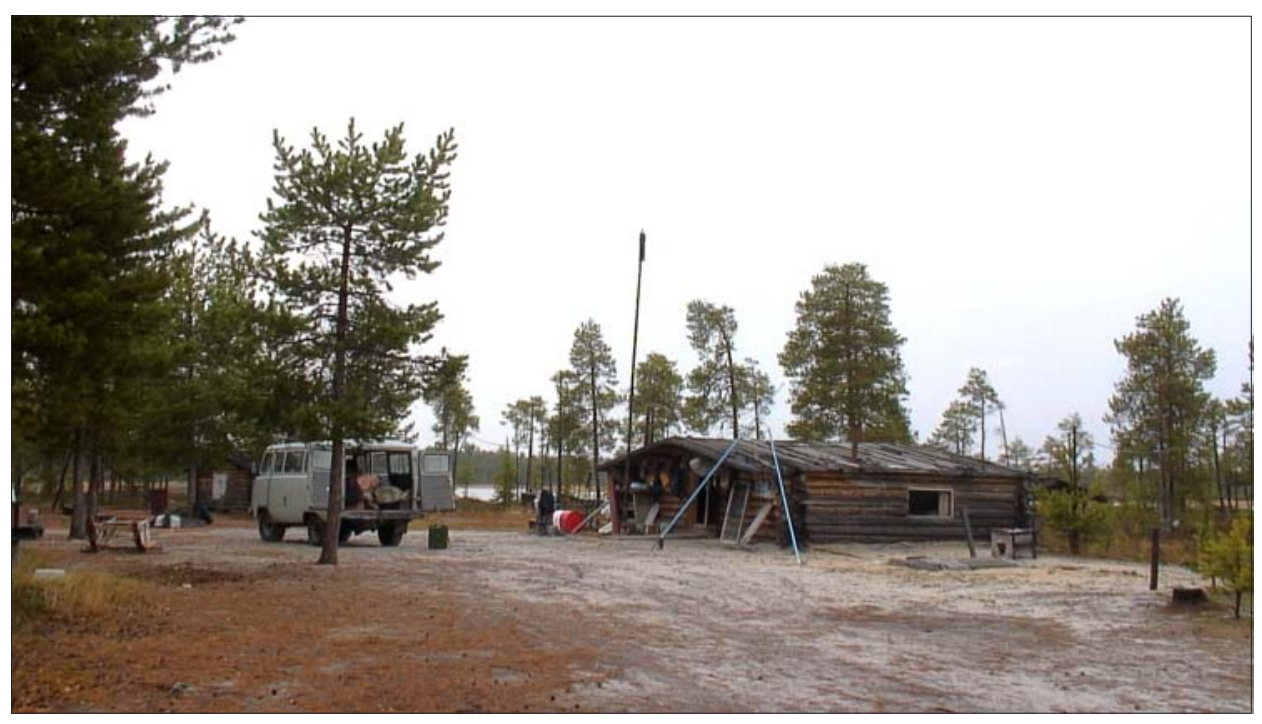

Yuri Vella's summer camp.

A still from author's video footage.

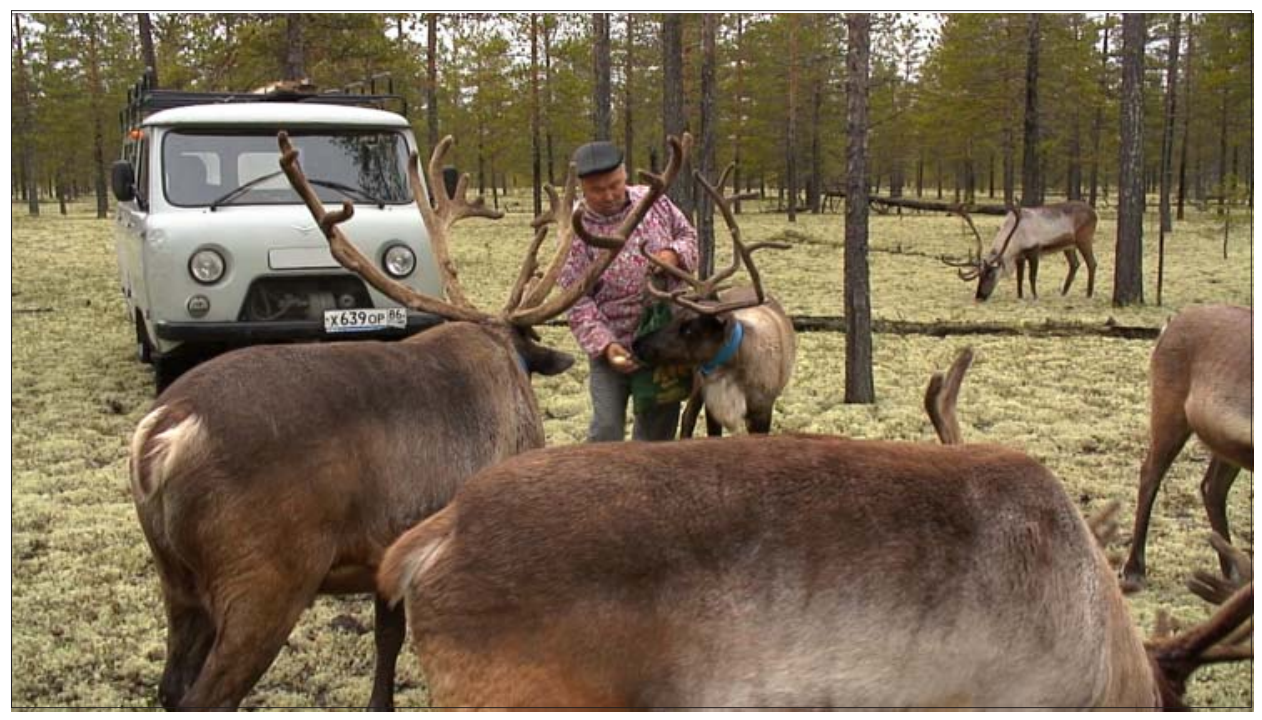

Yuri Vella, reindeer and uazik.

A still from author's video footage. 
When the water is frozen and the ground is covered by snow, Yuri drives a snowmobile to take care of his herd and to check the fish traps. Yuri was one of the first natives who started to use a buran ${ }^{7}$ - a classic Soviet snowmobile - in the area. According to Yuri, he was a member of the first experimental mechanized hunting brigade in Russia. The Institute of Hunting and Fur Farming, which was based in Kirov, formed the brigade in 1979. The aim of the brigade was to do research on hunting for fur animals, moose and wild reindeer. The brigade was provided with a snowmobile for collective use and it had a researcher from the institute as a member. Soon Yuri had saved enough money and he bought himself a personal snowmobile. There is no doubt that the snowmobile had a great influence on the mobility and subsistence activities of Yuri Vella and other indigenous people in Northern Russia. But it was not on the same scale as in Fenno-Scandia where the adopting of new technology brought along the rapid economic and social change in Sami society in the 1960s, which has been described as "the snowmobile revolution" (Pelto 1987; Helander-Renvalg 2007). ${ }^{8}$

The snowmobile continues to play an essential part in Yuri's everyday activities in the winter season. But I would argue that probably the most important feature of Yuri's mobility is his uazik. Unlike the snowmobile, it can be used throughout the year, and more importantly, it binds Yuri's forest home strongly with the outside world - physically, economically and politically.

Therefore, I was not surprised when viewing the video material I had shot over the years on Yuri, to find out that a substantial part of it was filmed either about or in the car. What did surprise me while watching the footage was the extent of the information communicated to the camera during the driving. Most of the data presented in this article has been recorded on the move. The camera captured not only what Yuri said while driving the car; it also registered how he said it and what was visible through the windshield or the side window of the car at that moment.

\section{FILMING IN THE CAR}

It could be argued that this emphasis on driving tells more about my preferences as a filmmaker than describes the reality of Yuri Vella's everyday life. It is true that filming in a moving vehicle is very common in fiction as well as in documentary film, especially when it comes to recording a dialog between film characters or an interview between protagonist and film director. The intimacy that occurs when being isolated in a moving car provides a suitable environment for actors or real life characters to be engaged in a natural and fo- 
cused conversation. Because it is what we do while driving - we talk to our fellow passengers; it is an essential part of "car culture". Filming in a moving vehicle allows also the showing of the geographical dimension of the action and to introduce the physical environment - land or cityscape that is passing by outside the windshield or the side window - as a separate character whom the actor or protagonist is reacting to while driving.

No wonder that episodes shot in a car can be found in almost every film, which tries to portray modern society. A car has become so deeply embedded in today's world that it is almost impossible to represent any cultural reality without it. Even the most remote corners of the human habitat are being overtaken by ever spreading "automobility", a concept that British sociologists and geographers have defined as "one of the principal socio-technical institutions through which modernity is organized" (Böhm et al. 2006: 3).

The car and all the material, social and cultural phenomenon that are interconnected with it, plays such a dominant role in our life that it is only natural to find its strong impact in audio-visual representations of diverse human societies; be it, for example, a comic Internet clip about a Warlpiri "bush mechanic" in the Western Desert of Australia who does "magic" on a dead car battery (Bush Magician...) or an art-house film on love, pain, divorce, and womanhood in Iranian society told entirely through conversations between a Tehrani woman and the passengers she picks up in her car (Kiarostami 2002).

The car is not just an instrument of modern technology that shapes our economic, political and social engagement with the world. There are also emotional and sensory dimensions attached to it. Or as Mimi Sheller has stated: "Car consumption is never simply about rational economic choices, but is as much about aesthetic, emotional and sensory responses to driving" (2004: 2). Sheller who is advocating "an emotional sociology of automobility" in order to find ways to turn today's car culture into a transportation system which is socially and environmentally more responsible, writes that this aim could only be achieved if we take "seriously how people feel about and in cars, and how the feel of different car cultures elicits specific dispositions and ways of life" (Sheller 2004: 4, original emphasis).

Interest in sensory and emotional aspects of culture is increasingly central to the social sciences and humanities because it has been acknowledged that sensoriality is fundamental to how we learn about, understand and represent other people's lives (Pink 2009: 7). Visual anthropology embraced the senses already a long time ago, if not in theory, then in practice (MacDougall 1998; Pink 2006; Grimshaw 2001) ${ }^{\mathbf{9}}$ and the use of visual methods and media in the anthropology of the senses is now common practice. For example, Sarah Pink finds that "the use of a video camera encourages a research participant to 
engage physically with their material and sensory environments to show the ethnographer their experiences corporeally." (Pink 2009: 105, original emphasis). She also acknowledges that the video camera introduces something of the reflexivity (ibid: 105), referring to David MacDougall's conception of "corporeal images". According to MacDougall "We see with our bodies, and any image we make carries the imprint of our bodies; that is to say, of our being as well as the meanings we intend to convey [...] Corporeal images are not just images of other bodies; they are also images of the body behind the camera and its relations with the world" (MacDougall 2005: 3).

Filming Yuri Vella in the car can be considered as a research method that helps to explore the specific environment he is acting and living in. The camera captures the way Yuri is physically engaging with the car while driving, it tells what kind of sensory "place" the car is and how he is using it. It also shows how he is experiencing and reacting to the environment that lies outside of the car. For example, some places along the road might provoke Yuri to verbalize certain memories and feelings, or show their reflection on his face. In other words, the camera provides the opportunity to understand and also to represent Yuri's embodied experience of driving the car in a particular environment.

The video footage reveals what it physically means to drive a car on Western Siberian roads. It shows the corporeal experience of the driver. It does so through the image produced by a filmmaker who has shared the same physical and mental experience. During the recording, the experience is filtered and manipulated by the filmmaker according to what kind of sensory environment he feels to be in and how he has felt in a similar environment before. Similarly, the audience's understanding of the protagonist' sensory experience is achieved by mirroring its own bodily memories from the past on the shown image. In both cases, the process of understanding is less intellectual than it is emotional and corporeal. The aim is to reach the kind of anthropological knowledge "in which meaning is not merely the outcome of reflection upon experience but necessarily includes the experience [...] the experience is the knowledge" (MacDougall 1998: 79, original emphasis).

\section{AUTOMOBILITY IN RUSSIA}

According to John Urry automobility can be conceptualized as "a self-organizing autopoietic, non-linear system that spreads world-wide, and includes cars, car-drivers, roads, petroleum supplies and many novel objects, technologies and signs" (Urry 2004: 27). 
Many of the characteristics of the Russian system of automobility have been inherited from its Soviet past; the most notorious features being bad roads and reckless driving. ${ }^{10}$ In the Soviet Union, cars for decades were reserved only for the political elite, the rest of the population traveled by overcrowded public transportation. The car became an affordable consumer item for Soviet citizens from the 1970s on, when the rise in living standards, drawn especially on the huge oil and gas reserves found in Western Siberia, coincided with the emergence of mass production of automobiles. ${ }^{11}$ But even then only a privileged few had the chance to buy. Like other goods in the shortage that characterized the Soviet consumer society, new cars could be obtained mainly through the exchange of favors, or through the semi-illegal economy. The best chance was to purchase a second-hand car, but its real market price was often higher than one had to pay officially for a new one. (Siegelbaum 2009; Zezina 2009; Gatejel 2009)

Getting the car was just one of the difficulties a Soviet automobilist had to go through. The lack of service stations and other infrastructural facilities, and insufficient investment in spare parts production, made it inevitable for car owners to find unofficial, often criminal, ways to take care of their cars. Siegelbaum has called it "a Faustian bargain". He uses this term to emphasize

the inevitability of automobile owners' reliance on heterodox and illegal practices that included hiring of labor, appropriating state property for private (again, "personal") use and profit, and diverting time away from the performance of one's job and other social responsibilities to the care and feeding of one's car (Siegelbaum 2009: 24). ${ }^{12}$

In the early 1990s the Soviet system collapsed and a car market opened for the wide range of Western cars and eventually the system of modern maintenance facilities like service centers and gas stations was developed. But even today, especially outside of the main urban centers, the functioning of the Russian automobility relies heavily on the features developed during the Soviet time. The car scene in Western Siberia, for example, is still dominated by domestic cars, many of them designed or even produced in the Soviet Union. Although the Russian market is full of western cars, most of them used right-hand drive vehicles exported from Japan, people preferred, until very recently, to own Russian-made cars due to the low price, simple design and access to spare parts ${ }^{13}$. There are more properly functioning gas stations and repair workshops than during the Soviet time, but people living in the deep periphery of the country have usually neither the means nor money to use them.

In addition to the car models and infrastructure, other aspects of Soviet automobility have survived in today's Russia as well. Answering to Siegelbaum's 
question about which practices of Soviet driving culture have been retained in post-Soviet people (Siegelbaum 2009: 29), I can state from my personal experience that, at least in Siberia: the little $G A I^{14}$ stations and the arrogant GAIshchniki are still on the main roads leading out of the cities; the general disdain for wearing seat belts has not disappeared, even though the buckle-up campaigns are frequent and the fines are high; the ubiquity of bribes to settle fines has persisted despite all the traffic police reforms; people still remove windshield wipers from parked cars to prevent theft; the cross-traffic turns are made on major intersections also today; the car owners still find ways to obtain fuel illegally, though it has become much harder; even the predominance of women among gas station attendants has not changed since the breakup of the Soviet Union.

\section{DRIVING A CAR IN WESTERN SIBERIA}

If there was no oil in the region, there would probably be no road infrastructure away from major historical centers. I realized how difficult it was to travel in the region prior to the oil development when we drove in Yuri's uazik across the bridge over the Ob River on our way to Surgut. As it often happens when traveling with Yuri, passing by a specific location loaded with his personal remembrance or with someone else's recollections, the bridge triggered the flow of a spontaneous but well composed narrative. This time it was about the death of his father.

It happened in the $1950 \mathrm{~s}$. His father was sent to Surgut by the administration of the kolkhoz in his native village Varyogan to fetch the big sum of money that was needed for running the kolkhoz. Back then, as there were no roads, the main mode of transportation in summer for indigenous people was a dugout boat. Yuri's father reached Surgut only to find out that there is no money and that he had to continue to Khanty-Mansiysk, a regional administrative center a couple of hundred kilometers down the Ob River. On the way back when he was staying overnight in Surgut his dugout was stolen and he was compelled to continue on foot. He traveled from camp to a camp, crossing bigger rivers by swimming while holding onto tree trunks. He consumed alcohol in one of the camps and next morning when he woke up in the forest he realized that he had lost the money. According to Yuri his father had an attack of panic and feared that he will be shot for losing the state money, which was quite a common penalty for this kind of misbehavior in the $1950 \mathrm{~s}$, and although the incident was eventually covered up by the kolkhoz administration, he lost his mental balance and soon after committed suicide. 
In the mid 1950s oil was first discovered in the basin of the middle Ob River. As a result great changes took place in the region: railroads and motor roads were constructed through the forest and swamps; the new booming oil cities appeared where before there were either small sleepy towns like Nizhnevartovsk and Surgut or reindeer herders' campsites as in the case of Kogalym and Raduzhnyi. The region has been the center of Russian oil production ever since, it is the home base for the two biggest oil companies in the country Lukoil and TNK-BP; and legendary Samotlor oil field, the largest in Russia and the sixth largest in the world, is situated here.

Although the road system that the state and oil companies have built since then is quite extensive, the quality and the maintenance of the roads are very poor. ${ }^{15}$

The aim is to extract oil with as little expense as possible. Therefore only the main roads are paved, those, which go to oil wells and are out of sight, are nothing more than strips of sand. Driving a car or even a big truck on this kind of road is very slow and difficult. The drivers try to find firmer ground off the road in the forest. The result is that there are often as many as seven or eight parallel roads going in the same direction. There are proper bridges only on bigger rivers. Constructing roads across small rivers and creeks quite often means just putting a metal tube on the riverbed and covering it by sand.

The oil industry's desire to save money and its indifference towards nature are also visible on the roadsides: while the main highways that connect regional centers are kept quite clean by Russian standards, the auxiliary roads going to oil wells are usually very polluted. Roadside litter there consists of garbage, oil pollution, leftover materials from road construction, and quite often parts or even entire bodies of heavy machinery like trucks and bulldozers. The omnipresence of the oil industry is felt also in the form of visual pollution: besides pine forest, swamps, lakes and rivers the typical roadside landscape in the region includes sand quarries, forest clearances, oil pipes running on the ground and through the lakes along the road, pump jacks working at oil wells, burning gas flares ${ }^{\mathbf{1 6}}$, etc.

The oil industry has occupied public space also by erecting imposing concrete and metal structures bearing oil companies symbols along the main roads and by having their logos written on huge oil tanks that are towering in various oil production sites. It is not that different from the American urban roadscape, which is "surrounded by a plethora of corporate logos, of McDonalds, the Ramada Inn and Mobil Gas" (Edensor 2004: 108-109).

All these features of the local road system - the quality of roads, the characteristics of roadside litter, the presence of the oil industry's infrastructure, the visibility of corporate symbols as well as particular flora and fauna - can be 
perceived as being part of a specific regional motorscape. According to Tim Edensor, who has studied motorscapes on a national level, the motorscapes are primarily constituted out of those "mundane spaces which are unreexively apprehended, serialized and recurrent" (Edensor 2004: 108). Familiar features, even if they are perceived as negative, constitute a sense of being in place in most motorized landscapes of Western Siberia, since the omnipresence of the oil industry and its influence on vernacular features and everyday fixtures embedded in local contexts recur throughout the region.

The piece of land where Yuri Vella is living and herding his reindeer is approximately $20 \mathrm{~km}$ long and $20 \mathrm{~km}$ wide. He moved there after the collapse of the Soviet economic order in 1990 from Varyogan, the village where he had lived most of his life. He took advantage of the chaotic situation in the legal system and reclaimed the area that used to belong to his parental grandmother as his "tribal land". It was also the place where his father had herded kolkhoz's reindeer and Yuri himself had worked as a state hunter in the end of 1970s and in 1980s. Yuri bought 10 reindeers and built a couple of camps with log cabins at the seasonal herding grounds in order to lead the life of a Nenets reindeer herder. The territory was not pristine however - it had been a site of oil exploration, but was abandoned during the downgrade of the Soviet economy. Yuri inherited the land, which had old exploration wells, some pollution and a few roads.

After a short interregnum the oil industry was booming again and by now Yuri Vella's home territory is surrounded by Lukoil's oil wells and other oil production facilities. This, besides causing a negative impact on quality of life such as pollution, noise and threat from poachers, provides Yuri and his family with relatively easy access to the local road system. The nearest oil well is just on the other side of the wooden fence that Yuri has erected to mark his territory and to prevent his reindeer to venture into the oil workers' "soup" (Niglas 2003). The road that is used for servicing the oil well is one of those typical cheaply built sand roads, which in spots is difficult for an uazik to drive on due to the deep sand and poor drainage. But there is varying regular traffic circulation on the road, which makes it necessary for Lukoil to maintain it at a certain level throughout the year. It means that Yuri and his family have the possibility to leave their forest home at almost any moment, provided that the weather conditions are not too extreme for the car.

How much Yuri Vella and other indigenous car owners depend on the oil companies' road systems was revealed when Lukoil workers tried to dismantle a bridge connecting Yuri's territory with the Varyogan village in the autumn of 2000. Yuri, who was taking his grandchildren in the uazik to the village school, drove towards the Hapleuta River and saw that a wheeled digger 
was tearing down the bridge. He realised that the destruction of the bridge would cut off the road to the settlements that the indigenous people went to get medical help, buy food, visit relatives, take children to school and deal with state institutions. In order to prevent the destruction of the bridge, he cut the digger's tires with an axe. The bridge was saved for the moment. Lukoil sued Yuri Vella for damaging the company's property and won the case (Niglas 2005: 120-122). But the bridge was eventually taken down. Yuri Vella, together with other indigenous families, built a new bridge away from the main road.

The new bridge is a real testimony to creative indigenous engineering. It is a kind of suspension bridge: strong boards are resting on two iron cables that are stretched across the river. The cables were found among the junk that had been left behind in the forest by oil workers. Yuri told me that it is actually the second bridge that they built in that spot - the first one did not survive the testing and was washed away by the river. So, there was always excitement in the air when Yuri drove his uazik over the bridge. He always insisted that we, the passengers, cross the bridge on foot. As the bridge is a few kilometres away from the main road and only a narrow uazik track goes there, the nonindigenous people do not know about it. Yuri showed me once, on our way to the camp, what was left of the bridge destroyed by Lukoil. When we got to the bridge we saw a car and people sitting on the other shore of the river. Yuri explained to me that they are waiting for their colleague from Novoagansk, the small town next to Varyogan, in order to take him to work in a Lukoil oil field. But first, someone had to give this man a ride from Novoagansk to the river and then he had to climb on what was left of the bridge to the other shore. It felt like deja vu from the heyday of Soviet absurdity.

Lukoil did not achieve its goal to discipline "un-cooperative natives", like Yuri Vella (Niglas 2005), but its strategy to restrict traffic near its oil-fields, which was the official explanation for disassembling the bridge, was, at least partly, successful. Because of the new bridge, local indigenous people can again use this vital road, but they cannot drive on it during winter. When the old bridge was still there, the road was kept clear of deep snow by trucks that took people and goods from the big settlements like Raduzhnyi or Novoagansk to the oil fields and beyond. Now, when there is a lot of snow and Yuri Vella wants to get to Varyogan, which is about $130 \mathrm{~km}$ from his camp by the old road, he has to make a huge detour and drive about $650 \mathrm{~km}$ using roads that are maintained all year around.

In general, Yuri Vella's forest home has a relatively good connection with the outside world via the oil companies' and state road system. But on the other hand there are psychological constraints that make the use of this infrastructure problematic. For example, Yuri Vella is reluctant to drive to the local 
centers because he perceives them as hostile spaces; partly because he is not that confident about driving in a busy city, but mainly because these are the environments, which are demonstratively controlled by the political and/or oil authorities. Typically for Russian automobility, roads leading to bigger towns, for example to Surgut, Nizhnevartovsk or Kogalym, have little GAI stations on major intersections and at entrances to the cities. These traffic police stations are manned with GAI-shchniki whose main purpose is to stop cars for inspection of driving licenses and other documents, which is usually carried out with a suspicious look in their eyes and by asking questions about the purpose of the trip. In the oil rich region of Western Siberia, there are also checkpoints on smaller roads operated by the oil companies' security forces. For a native person it is a dubious situation to go through the inspection points: on the one hand the natives are usually looked down on by those who have power in Siberia, especially by a low-ranking policeman or a security guard; on the other hand, the issue of indigenous rights and the land has made local authorities and oil companies very careful in their relationship with natives living in the forest. As Yuri Vella has been in a conflict with both local powers for years, he is always afraid of being harassed when driving through the inspection points. And, before driving through a checkpoint, he always puts on a cotton malitsa - a traditional summer cloth for native men, to emphasize his status as an indigenous reindeer herder.

\section{MAINTAINING UAZIK IN THE FOREST}

Most of the Westerners are increasingly seeing cars as "sealed objects where users are discouraged, even penalised, for interfering with them [...] by the complexity of the objects, the cost of specialist tools, and the risk of having a warranty voided" (Clarsen 2002). But people living in the remote areas of Russia, for example in Western Siberia, still prefer to repair their cars themselves, often sidestepping the cash economy and using the methods of "bush mechanics"17 to get their vehicles fixed.

Yuri Vella rarely takes his uazik to an authorized mechanic. This means driving to some bigger town and spending a considerable sum of money. $\mathrm{He}$ tries to stock up on the necessary spare parts whenever he happens to be in a local city in order to avoid extra trips for maintaining his car.

Very often he repairs the car himself. He has constructed a simple car lift made out of scrap metal plates found in the forest to allow better access to the car from underneath in his summer camp. But whenever possible he prefers to delegate more serious or time consuming repairs to a relative or a friend. In 
more difficult cases Yuri asks his son-in-law, who has the necessary tools, skills and expertise, to fix the car.

Kolchu and Anton, the two teenage grandsons living with Yuri Vella in the forest since they were small, are helping to take care of the car too. Their duty is to prepare the car for driving, and if necessary change a flat tire, refill the fuel tank, or change light bulbs.

The closest place to get professional help is a truck depot of the local Lukoil unit, about one hour drive from the forest camps. Yuri Vella goes there when he needs to do something on the car that requires using special equipment, welding or fixing a broken car battery, for example. I have been to the truck depot with Yuri once, in summer 2009. It was fascinating to see him negotiating with the head of the depot to get his things done. They engaged in a kind of humorous conversation, which mainly consisted of jokes at the each other's expense that sometimes bordered on verbal abuse. As the men represent two different, even opposite, value systems, they have to communicate in a situation in which conflict and rivalry is very likely but must be avoided, much like in a classical joking relationship ${ }^{18}$. It is possible that their conversation had this character partly because I was there with a camera. But even if they did "perform for the audience", they did so by applying their standard modes of behavior in a given situation; the camera's presence just brought it out more clearly. ${ }^{19}$ The men parted without giving each other any clear promises, but their partnership was once again reinforced: Yuri had shown his need for help in a specific case, while the head of the depot emphasized the more informal nature of their relationship by sending a jar of melted fat to Yuri's wife as a present.

On our way back home I asked Yuri, on camera, how he feels about using the oil workers help. He said that he and the local oil workers try to co-exist without disturbing each other too much. But sometimes they ask favours from each other. Yuri explained that the Nenets term for this kind of partner is the word t'iL'u, which means a person who takes care of you, who sees that you have everything you need. ${ }^{20}$ Yuri's t'iL'u is the head of the truck deposit. If it was not him, someone else would have to fulfil this function. Explaining the system of their partnership he gave me an example. I transcribed it fully from the video footage in order to demonstrate his way of reasoning, which combines the phenomenon of a t'iL'u with his personal life, the wrongdoings of Lukoil and state law into a well-structured narrative. Unfortunately I cannot convey in this text his voice and facial expressions while he was telling me, neither can I make you feel with your body the bad quality of the road we were driving on, nor show the sandy wasteland and rusty oil pipes that were passing by our side window. Yuri said: 
Sometimes I get from him fuel, diesel for the electric generator, a little gasoline for the car, sometimes kerosene for a lamp, small things like that. Is he buying it for me? No, he takes it from his company, he steals it like we say in Russian; if to put it bluntly - he steals it from his company for me, gives it to me. That's why he is needed, in principle. Because, firstly, the closest gas station is far away. Secondly, we do not always have money to refill the car. Thirdly, I understand well that Lukoil occupied our lands: if Lukoil had not come here, we would maybe have been able to sustain ourselves here. If Lukoil was not here (showing out the front of the car with his hand), I would not graze my reindeer somewhere there (showing to the right), but somewhere here (showing to the left), closer to Varyogan. I would have more land to herd the reindeers, I would have maybe a bigger herd, by two-three times... For example, I am still not selling reindeer. The herd is still small. But if the oil field was not here, I would maybe already be selling reindeer meat. But Lukoil, so to speak, is slowing me down, is slowing down our efforts to live better. It means... it is completely logical, that Lukoil should compensate these losses, and in the law it is written that Lukoil should compensate. We concluded a contract. When Lukoil needed my signature, Lukoil concluded a contract with our family, promised us this and that, including fuel for our family. One year passed. When I started to tell Lukoil that here you are spilling (oil); here you are not doing the right thing; here you have no need to drive, but you drive... Lukoil got tired of hearing it and Lukoil decided to teach me, decided to teach our family a lesson - and stopped paying according to the economic agreement. I know perfectly that I am right, Lukoil had to pay it. Further, the economic contract terminates in the case we both - we both concluded it, right... According to the civil law, either we both agreed to determine it or the court... when one side wants to determine it but the other does not, then this one side has to go to court and the court has to determine the contract. There was not that kind of determination by the court, it means that Lukoil up to now owes my family fuel and money and etc. Therefore, I think that the fact that the representative of Lukoil steals for me fuel, means that I take what belongs to me, I take what Lukoil owes me.

Yuri told that as a return favour for getting his car repaired or acquiring some fuel, he provides his partner now and then with reindeer meat and sometimes lets him drive onto his tribal land to catch fish or hunt grouse. It seems that the automobile owners' reliance on heterodox and illegal practice is still going strong in today's Russia. Hopefully Yuri Vella and other indigenous car automobilists do not have to pay too high price for their own "Faustian bargain". 


\section{UAZIK AND REINDEER}

In Western Siberia the most important traditional mode of transportation has been reindeer. While some indigenous peoples in Siberia ride their reindeer (Evenki, Evens, Dolgans), the Nenets and the Khantys use reindeers as draft animals to pull wooden sledges (in Russian: narta). In the arctic zone of Western Siberia, where the poor nutritional quality of tundra vegetation compels people to graze their herds on a vast territory, the reindeer is used for transportation throughout the year (Niglas 1997). In the forest zone, reindeer herding is local, and reindeer-driven sledges have been used only in winter, along with skis. In summer, the main means of transportation has traditionally been a dugout canoe.

Today, traditional modes of transportation have been replaced by modern technology in many places. There are great regional differences in using cars, snowmobiles and motorboats in Western Siberia. As was demonstrated in the previous chapter, the area of the Middle Ob River where Yuri Vella lives has relatively good infrastructure for fuel driven transport due to the long presence of the oil industry: the road system is quite extensive; spare parts and service centers are accessible in bigger towns and oil production sites; and there exists both legal and "un-official" ways of obtaining fuel.

This is in contrast, for example, with another region where the Forest Nenets live as a distinct and compact group - the Num-To area, which is much less developed. The village of Num-To has been described as one of the poorest places in Siberia (Salminen 1997: 95-96). There is no permanent road that connects it with other settlements and it can be reached only by helicopter, that flies once a week from the city of Beloyarsk. But the oil and gas producers are already working in the area and probably the use of reindeer for transport will decrease soon due to better infrastructure and the loss of herding land. When I was visiting Num-To in winter 2004 many indigenous people were driving reindeer sledge, and those who had snow mobiles had to make a big effort to find fuel, at times travelling long distances to obtain oil and gasoline from an oil production site.

Yuri Vella has always wanted to live with reindeer. Since he grew up in a village, his contact with reindeer in childhood was limited. He recalls how he envied his schoolmates who were brought on reindeer sledges to the village's boarding school from their forest homes (Niglas 2003) or when during the school holidays their fathers came to pick them up from school with an extra reindeer sledge for the children to drive home. He also remembers vividly those moments when he could accompany his relative Aatan on a reindeer sledge to take hay for kolkhoz' cows and horses, and that on the way back Aatan allowed him to hold the reins (Vella 2008: 137-138). 
Yuri has never really used reindeer for transport. Before he began breeding reindeer, he became accustomed to the snowmobile while working as a professional hunter. Although Yuri is very keen on making sledges and other necessary items for driving reindeer, he harnesses reindeers in front of a sledge very seldom, usually to entertain himself or his grandchildren. As he explained in summer 2009 while making a driving pole ${ }^{21}$ with an axe:

Last year I drove reindeer 3-4 times. But you see - if you need to go to get fish (from a fish trap), you first have to round the reindeer up; then catch it, then harness it to the sledge; and then drive ... on the speed of an animal; but an animal can go about $20 \mathrm{~km} / \mathrm{h}$. It is slow. But here... you drink the tea, go out of the house, do one move (making a gesture as pulling the starter rope to start the engine), the snowmobile starts and off you drive. And you drive $40 \mathrm{~km} / \mathrm{h}, 50 \mathrm{~km} / \mathrm{h}$ - it is two times faster. You check the fish trap and return quickly home. And you can drive far in one day. This is the advantage of buran over reindeer. On the other hand it is more interesting to drive reindeer: if there is nothing to do, one can drive reindeer; reindeers go slowly, during that you can contemplate, think and philosophize.

Before Yuri had a car, he used the snowmobile for long distance travel, for example to get from his forest camp to the village of Varyogan in winter. It took about 7-8 hours to cover a distance of $100 \mathrm{~km}$. Sometimes he drove his snow mobile to a "friendly" oil production site and hitched a ride from there. Driving long distances on a snowmobile, especially on a Soviet designed buran, is physically very demanding. Not only is it difficult because of the weather conditions (cold, wind, snow), it is also very hard on a driver's arms, legs and back. It is no wonder that Yuri tries to drive his uazik all year round. Sometimes it can be difficult, too. For example when it is below $40^{\circ} \mathrm{C}$ outside and the oil in the transmission joints of the car has congealed, and Yuri has to spend hours heating up the gearbox with a kerosene blowlamp; or in the case when he has to avoid bigger snowdrifts on the open road by navigating his way through the forest. Driving on bad roads with a Soviet designed and Russian built car that can break down any moment, turns any long trip into an adventure. It is not wise to travel alone, and usually it is Yuri's wife Lena who accompanies him on car trips with prepared food and thermoses filled with hot tea.

In the above-mentioned statement Yuri links the activity of driving reindeer with certain mental processes, like thinking, contemplating and philosophizing. In this regard, the driving of a reindeer sledge seems to be very similar to driving a car. Both activities facilitate a certain state of mind that is suitable for contemplating. One form of it is singing. Yuri sings very often 
when he is driving his uazik. Yuri has said that: "singing while driving, either loud or in thought, helps - the hands are on the steering wheel but brains are singing".

The songs he sings are as diverse as his life experiences. It can be a popular Russian song he learned while doing his military service in the Soviet army or the song he heard from a Nenets shaman. Watching Yuri singing in the car brought back memories from my fieldwork among the Nenets reindeer herders of the Yamal tundra. Driving on a reindeer sledge when migrating to a new camp or visiting relatives seemed to provide the Nenets with the necessary environment for singing - unlike a crowded campsite or a tent shared by many people, driving alone or with small children on a sledge creates the private space that facilitates the singing of one's own or someone else's personal song.

There are other points of similarity that can be drawn between a car and a traditional way of life. On our way back to the camp after driving to Kogalym or to the local Lukoil truck dept, Yuri often remarked that a Nenets does not like to return home by the same way he left - it is more interesting to choose a different route for going back. Typically for him, he was referring to a traditional folk concept in order to explain and justify his engagement in the modern world. It was almost like he was stressing that after a short detour in the reign of money and oil we return to the land of tradition and reindeer, "forgetting" that he is not holding reindeer reins but the steering wheel of his car in his hands.

The connection between driving a car and driving a reindeer in Yuri's thinking is very clear when he talks about hahu. According to Yuri, the hahu is the skill of finding one's way through the forest. It is seeing one's surroundings from different angles, simultaneously rather than as a flat, two-dimensional picture. Only the Nenets have hahu: when a Nenets drives on a narta, he always finds his way between the trees, he never takes out his axe to clear the way or to cut down a tree; but a Khanty has to work hard with an axe in order to drive his narta through the forest. That is what the Khantys are saying about the Nenets and the Nenets about Khnatys, because the two people have lived together for a long time and they know each other well, says Yuri. Yuri was telling me all this while slaloming the uazik between the trees in order to bypass a spot of deep sand on the road.

When I commented that it seems that a Nenets drives a car like he drives a narta, Yuri smiled in agreement and went on by saying that the way a Nenets is driving his narta is determined by the reindeer, because his conscious is subordinated to the life of a reindeer. Yuri added that he will show me later a reindeer bull, whose antlers are as wide as a uazik, and despite that it always 
finds its way through the forest. He laughed and concluded the topic by stating that it is because: "a Nenets is like a reindeer, or maybe reindeer is like a Nenets".

\section{HERDING REINDEER WITH UAZIK}

When Yuri Vella moved to live in the forest, he had to learn how to look after his reindeers. Even now, after 20 years of experience, he often repeats that he is still just "a young reindeer herder" with moderate skills. He doesn't say it because he is modest or because he does not want to compare himself to those who have lived with reindeer for all of their life. He really thinks that way. This is evident from the way he acts whenever he is dealing with his reindeer, for example, when he has to take the herd to a new pasture or catch a reindeer in a corral: he becomes very cautious, even nervous, and is usually not pleased when I try to film him. It seems that he is not completely sure that he is taking care of his herd in the right way, that the more experienced herder may do it differently. It could also be partly the reason why Yuri Vella is always so anxious to know where exactly his reindeers are located and how they are doing.

Yuri Vella has about 100 reindeer, which is not that small a number in comparison to some other families in the neighborhood. The Forest Nenets and the Khantys who live in the region have traditionally had small herds; the reindeer were mainly used as draft animals while most of their livelihood came from hunting and fishing (Verbov 1936). Unlike in the open tundra of Yamal Peninsula, where herders monitor big herds (up to a few thousand heads) constantly working in 24 hours shifts (Niglas 1997), the reindeers in the area of Middle $\mathrm{Ob}$ River are grazing unguarded in the forest. In order to prevent the animals from becoming wild, it is necessary that the herder has regular contact with his herd.

Yuri Vella likes to visit his herd as often as possible. He knows that if the reindeers are left alone for too long, they will be afraid of people and it would be very difficult to control them. ${ }^{22}$ Another reason why he makes an effort to go to see his herd is to make sure that all the animals are there and, if necessary, direct them to another pasture. As various oil producing sites are surrounding Yuri Vella's territory, it is important to prevent the reindeers from venturing to an oil-well or to a main road, where they would be an easy target for oil-peoples' dogs and guns. Yuri has lost quite a few reindeers for unknown reasons and he is seriously concerned about poachers on his land.

In winter, he goes almost every morning to the forest to find the herd and to bring it back to his winter camp for the day. For that he has to predict the 
location of the animals by considering their natural instincts and feeding habits as well as the characteristics of the environment and the weather conditions. If he does it accurately and the herd is not too far from the camp, then it can take less than an hour; but if he has his calculations wrong he might spend hours searching for reindeer tracks. Once the animals are in the camp, Yuri and his wife feed them dried bread or fish soup while talking fondly to them in the corral. Yuri lets the reindeers free at dusk. He tries to direct the herd towards the desired pasture by opening one of the many gates of the corral.

The calving period in spring can be also very intensive for a herder: it is wise to monitor newborn calves in order to minimize lost lives in the cases when a calf cannot keep up with its mother or when the weather gets too cold.

Looking after ones herd is easier in summer, because the reindeer is herded "by smoke": animals come to the people by themselves in order to get protection from mosquitoes, horseflies and gnats in a so-called reindeer house (in Russian: olennyi dom). It is a big log structure with a roof and a fireplace in the middle. Burning either fresh moss on an open fire or firewood in a closed container produces the smoke, which keeps the insects away from the herd.

And even in autumn when reindeer are occupied with reproducing, it is wise to keep an eye on the herd. It is very important that as many cows as possible have the opportunity to get a bull. The herder has to ensure that each group of cows have a bull among them, and that nobody disturbs the animals during the rut, because the cows are accepting bulls for a very short time (some only during 3 hours during the entire rut) and there will not be another opportunity.

Regardless of the season, Yuri Vella tries to visit his reindeers as often as possible even if they are far away from the camp. In winter, depending on the weather and the snow conditions he either walks, skies or drives a snowmobile, often combining all three, in order to find his herd. He continues to use the snowmobile until there is almost no snow, trying to drive mainly on frozen lakes and wet moss. From late spring till winter he has to walk a lot, sometimes combining it with rowing the dugout canoe, if he wants to see how his animals are doing in the forest. But whenever possible, he prefers to drive his uazik.

Yuri Vella is not a young man anymore ${ }^{23}$ and over the years he has had his share of travelling on foot through the swamps and pine groves in his tribal land, first as a hunter working for a kolkhoz and later as a private reindeer herder. It is not just the walking he is tired of, it is also the carrying of a gun, axe, a teapot, some food and other necessary items needed when hiking in the forest. Driving a car makes travelling much easier and faster. An Uazik might not be a comfortable car by western standards, but it is a very convenient one 
when it comes to camping in the forest, carrying a dugout canoe, or taking a couple of reindeers from one place to another. As I will demonstrate below, the car is also suitable for tracking reindeers.

When I was visiting Yuri in summer 2009, I often accompanied him when he went to look for reindeers that had not been to the reindeer house for some days. Yuri went to fix the fire in the reindeer house a few times a day and often took with him some dried bread for the reindeers that were resting in the smoke. Therefore, he knew well which ones were missing and for how long. If some reindeer had been away from the camp for too long, Yuri got worried and went to search for them. Usually we went by car. We never knew how far we would have to go and, as it is very hard to see animal tracks on vegetation, it was better to stay on the sandy road where the reindeer tracks are clearly visible. Yuri also told me that reindeer actually prefer to walk along the roads. Sooner or later we saw tracks and Yuri examined them in order to determine which direction the animals went. Quite often he did not even get out of the car, he just drove slowly, backing up his uazik whenever he needed to have a closer look at the tracks. When we found the missing reindeers resting on the road or eating lichen not far from it, Yuri put his head out of the side window of the car and told them to go home. Sometimes we drove like this - reindeers slowly running in front of the car, with Yuri, his head out of the window, yelling at them to move on - for a few kilometers in order to make them return to the rest of the herd.

\section{NOMADISING WITH UAZIK}

In the forest area of Western Siberia, the reindeer pastoralism is traditionally practiced in the form of semi-nomadism. Tim Ingold has referred to this type of migration pattern as fixed-point nomadism - the movements of people are tied to the center with regular use of peripheral locations (Ingold 1987: 187). The herd is moving between seasonal pastures that are not very far from each other. People try to be close to their animals and move between different camps according to the season. The distance between the camps is in general quite small, from five to twenty kilometers. There is usually one main and two or three peripheral camps. Winter camp is usually the main one and consists of a few log buildings - one or two cabins for living, some storage huts and a sauna. A summer campsite has in general fewer buildings than the winter one, but as people live there for a few months in a row, it has to offer them enough space and comfort. In spring and in autumn, people camp near the seasonal pasture only for short periods and then they stay mainly in small huts or in tents. If 
necessary, for example, when a seasonal pasture is overgrazed or there is not enough firewood in the vicinity any more, a camp can be moved to a new location, either by constructing new houses or bringing dismantled buildings from the old campsite.

Yuri Vella has built many camps over the years. His winter camp lies in the thick pine forest, which shields it from cold wind. The summer camp is situated on a windy area between lakes in order to keep mosquitoes and horseflies away from reindeer and people. He also uses a temporary camp to be close to the herd during the calving period in spring. Before it was always a chum, a conic tent that the Nenets and Khantys have traditionally used as a dwelling place. Recently it has been "the house with stripes" - the bizarre, UFO-looking building that stands high up on "skis" and is painted in camouflage (hence, the stripes). In principle, a tank-like "all terrain vehicle" (in Russian: vezdehod) could pull it to a needed spot. ${ }^{24}$

Traditionally people moved from one camp to another by reindeer. Castrated bulls, in poorer families also cows, were used as draft animals to take sledges loaded with people and household items to the next seasonal camp. When Yuri Vella and his family are changing camp, they usually drive a car. There is a good, for the most part, wide and straight road between his summer and winter camp: a state company that explored for oil during the Soviet time had to construct the road in order to bring in an oil derrick. Although the physical act of travelling to the new camp has become much faster and easier because of the car, the psychological and emotional side of moving camp has not lost its importance. In May 2001, I filmed how Yuri and his family moved from the winter camp to the summer camp. Yuri's eldest daughter with her husband and three children were also living in the forest then; they lived in a separate house and used another uazik for travelling to the new camp. There is a sequence in Yuri Vella's World that shows both families packing their stuff on uaziks, driving to the summer camp and unpacking there. In the film the edited sequence lasts about four minutes. Viewing the unedited footage with the original time displayed, I realized that it took more than 4 hours to load the cars and only less than twenty minutes to drive it to the next camp. Besides time, both the film and the footage reveal the overall atmosphere of the event: the cheerfulness of the children that are trying to help the adults to load the cars and play at the same time; the stressed adults, telling the children not to be in the way; the restless dog barking in over-excitement; the suspicious cat sneaking around the car. The excitement is in the air and nobody is indifferent. Yuri sums it up by saying to the camera: "So, how is your mood? The Nenets say that travelling to the new place, to the new camp, is always a party?" Almost ten years later, in 2009, while loading the uazik for a 
trip to the autumn camp, Yuri repeats the same thing, this time adding that his grandmother wore three or four layers of festive dresses on top of each other for this important event. This statement is contradicted a few shots earlier in the same sequence, when Yuri's wife comes out of the house to get ready for autumn camp and mumbles to herself: "I am fed up with this constant moving." This certainly demonstrates that while Yuri likes to link his deeds with the traditional worldview, his wife acts more in the real moment. But it also emphasizes the fact that the reasons for moving camps have changed since the times of Yuri's grandmother. Constructing and visiting different seasonal camps is not anymore just a way to be close to ones' reindeer. It has become a necessary strategy to manifest the herder's rights to certain pieces of land. The visible presence of indigenous people, achieved by building a hunting cabin or being there in person, reminds the outsiders that they are trespassers on someone's property, that the area is not a "white spot" on an oil company's map, that it is not a place to be exploited for corporate or personal needs.

\section{ON THE LAND OF LOVE}

Yuri Vella built a new seasonal camp in the autumn of 2009. He had planned it for quite some time. A part of his herd had been going to the area next to the Vatyogan River for the last three years. Reindeers like to come there in late summer and autumn, because it has a wide pine grove with plenty of mushrooms and it is further away from the noisy oil wells. The place has become a main rutting area for one of the reindeer groups, which had separated from the main herd. Yuri explained that when the herd is getting bigger, he has to keep more bulls in the herd to make sure that all the cows have a chance to get impregnated. But the bulls compete with each other and more powerful ones share the herd between them. Usually there are two or three separate groups of reindeer during the rut.

Yuri Vella was very concerned about his reindeers in the Vatyogan area. This area is part of the territory that was assigned to Yuri as his tribal land at the meeting between the representatives of Lukoil, the administration of Surgut county and local indigenous family heads in the beginning of 1996 . But the decision was never officially approved and the only document that shows his connection to the place is a paper, which states that it used to be his hunting territory when he was a state hunter. In autumn of 1996, less than a year after the meeting, the area on the Vatyogan River was given by a governor's resolution to the hunting society of Lukoil. Yuri found out about it only recently by 
chance (an official showed him the document, although he did not have the right to do it). The legal status of the land is even more complicated than that: in the middle of 1996, the area was declared as a land reserve (licensed land unit of South-Vyatoisky), where hunting, berry picking and driving is prohibited. The license agreement, which bears the signature of the governor and representatives of Lukoil, also admits that Yuri Vella has a tribal territory there $^{25}$. Understanding that the area he needs for reindeer herding and considers as his tribal land has been actually given to Lukoil's hunting society, compelled Yuri to take action. Firstly, he became a law student in order to clarify his legal position in the case, and secondly, he decided to build a camp on the disputed land. As Yuri phrased it: "We have to start fighting again with Lukoil; the new conflict begins. And the governor sends again someone to deal with it... (laughing)".

Yuri dismantled an old hunting cabin in the summer camp and brought it by uazik to the Vatyogan area. He had chosen for his autumn camp a site on a narrow pine grove between a river meadow and a swamp. It is the spot where about 80 years ago his maternal relative Yussi Kampki set his hunting traps. Yuri had dreamed to live in this place for a long time, because there is a spring with clean water next it. But the place has another strategic value as well: the road built years ago for oil exploration goes through the campsite. Yuri says that the road helps him to look after his herd - the reindeers like to walk along the road and their tracks are visible on the sand of the road, therefore it is easy to find them by car. Having a camp in the middle of the road serves one more purpose for Yuri. It makes his presence in the disputed area more visible, and it also forces people who want to hunt or fish in the area on the other side of the camp to knowingly commit an act of trespassing by opening the gates in the fence that surrounds the camp. It was a clear message for Lukoil workers: "Look, the indigenous family is living here and you have no reason to be here." For me it looked like a declaration of war. Yuri was aware of its possible consequences. About ten years ago someone burned down the cabin he was using when working as a hunter. It was located just three kilometers from the present camp. Yuri thinks that Lukoil people, who wanted to have the place for themselves in order to fish in an old riverbed that was near the cabin, burned it down. When we visited the site we found that it had become a camping place with a table and chairs and lots of empty beer cans littering the ground.

When I started to film Yuri Vella in summer 2009 I did not intend to go back there for the autumn. But towards the end of my stay Yuri insisted that I should come back and film the reindeer during the rut. He pointed out that, as he will build a new camp in the Vatyogan area, there would most likely be 
encounters with oil workers and it could be good material for the film. It was clear to me, that besides thinking about the film, he was hoping to use the camera's presence in his fight with Lukoil. When I returned in autumn, I told Yuri that I can stay with him only for a couple of weeks this time. Yuri replied that he hopes we find some oil workers before I have to go back. And we did.

\section{THE DAY OF ACTION}

We moved from the summer camp to the autumn camp the very next day I arrived in the forest in September. I decided to record the changing of the camp with my camera. By the end of the day I was physically and mentally exhausted, and had filmed four hours of exciting footage. What follows is a description of a long day filled with fast driving, bold bluffing and clever use of modern technology. The tactics Yuri Vella used that day to achieve his political ends are similar to those employed by indigenous groups in other parts of the world, like, for example, the Kayapo Indians' appropriation of video cameras for conflict with the Venezuelan state (Turner 1992), or the Zapatista movement's use of Internet technology to mobilize their struggle for autonomy in Mexico (Kowal 2002). Yuri Vella's "guerilla" tactics - the use of video camera and access to the Internet combined with the element of surprise and extraordinary mobility, seem to be very effective in the fight for his indigenous rights.

We noticed truck tracks already at the barrier gate built by Lukoil that was supposed to protect the Vatyogan area from the outsiders. On our way to the camp we came across a group of reindeers resting by the road and used the opportunity to feed them some dried bread. Suddenly Kolchu noticed a truck speeding in the distance. Yuri, after some hesitation, ordered us to take our seats in the uazik and we started to chase the truck. When we were catching up with the truck, Yuri said: "Liivo, main thing is [to film] the number plate and the face of the driver, the driver or whoever there is... I need this shot." When I asked what he needs it for, he replied that there will soon be a session of the regional Public Chamber on ecology ${ }^{26}$ and he will raise the question of Lukoil vehicles violating the license agreement by which it is outlawed to hunt, fish, pick berries in the area. He also told Kolchu to get out his camera and film the truck. Finally the truck stopped and a young man wearing a black-and-red jacket with a Lukoil logo came out of the cabin. Yuri and Kolchu jumped out of the car. I hesitated to leave the uazik. Although my papers (visa, registration) were in order, filming on the company's premises could have caused problems both for Yuri and for me: in the Russian North, the people in general, and those with power in particular, are highly suspicious of foreigners 
with cameras. But then Yuri asked me to get out and film the number plate of the truck and the driver's face. When Yuri opened the door of the truck, the driver turner his face away. The man in the Lukoil jacket kept saying. "What is going on? What is the problem?"Yuri told him in an agitated voice about the license agreement; about Kolchu's cow who disappeared here last autumn without any trace; about his hunting cabin that had been burned down. Yuri kept repeating phrases like "tribal land", "license agreement", "reindeer", "camera", "general director of Lukoil" and "governor" while the man tried to impress Yuri with his official position and influence in the company. He was obviously disturbed by two cameras filming him from a very close distance. Probably the man would have reacted to Yuri's approach and to the presence of cameras in a different manner, if he had been sober. Both his verbal expressions and body language were those typical of a drunk Russian man. He put his hand on Yuri's shoulder, trying to persuade him not to take the case to his superiors. He promised never again to come to the area and offered to help Yuri out whenever needed. But Yuri was very firm and told him that the video clip will be shown at the session of the public chamber and declared that: "It is high time to punch your general director in the nose". The Lukoil man was disappointed and his face turned serious.

When we were driving off from the truck, Yuri was very satisfied. He had once again defended his territory and had sent a message to the Lukoil people that it is not wise to mess with him. He also possessed video material he could use in his fight with the oil company and local authorities as the license to use the Vatyogan area could be taken from Lukoil if its workers violate the agreement. For me the entire incident had been very un-nerving, I was afraid that the oil workers (besides the drunk man and the driver, there were some people sitting in the wagon of the truck) might try to get hold of the video footage; and as at least some of them were drunk and probably there were also firearms in the truck, it could turn ugly very easily. I asked Yuri if he was afraid of any consequences of this incident, he answered with irritation that there won't be any, the oil workers would not do anything to us. A bit later, after some thought, he added that the most the oil workers could do is to come back with police and check our papers. And he continued with a smile "But our papers are in order, right?" But I sensed that there is more to this than that.

When we finally reached the autumn camp we unloaded the uazik. As so many things had happen since the morning and Yuri was obviously in a very good mood, I wanted to get on camera his reflections about the whole issue with Lukoil in general and with the Vatyogan area in particular before the excitement of the day "cools down". Yuri was in good form: he gave me a lengthy explanation why he was so diligently fighting with the oil company and how he 

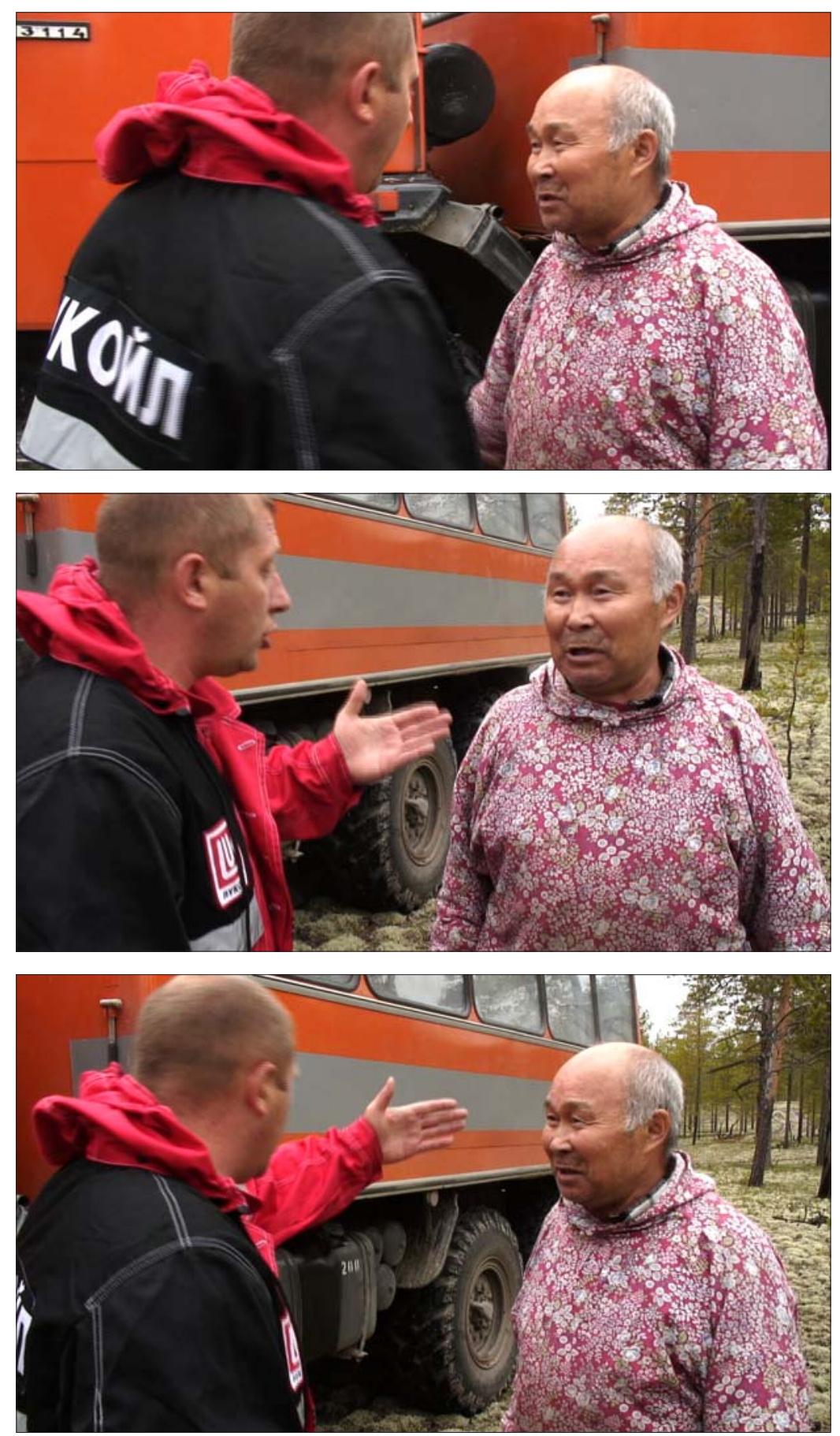

The incident with Lukoil workers. Stills from author's video footage. 
would hold on to his tribal land as long as he could without signing anything for Lukoil. In response to my question about the use of a video camera in the incident, Yuri told that when he still had the old camera, he tried to record all his encounters with oil people or representatives of authorities on video. But the camera broke down some years ago. A few months before the incident, in spring 2009, Yuri Vella had been given a new camera by the Regional Multimedia Center of Clans project at the Yugra State University in Khanty-Manziysk. ${ }^{27}$ Yuri was eager to use this technology for his political ends.

While my camera was still running, Yuri took out his mobile phone and called someone at the Multimedia Center. He told the person about the incident and asked whether the center would upload the video clip of the encounter on their Internet site. Although the person said that they would, Yuri remained skeptical, reminding that previously the center had censored a similar piece of information before putting it on the site. Yuri had switched the phone on loudspeaker and held it towards the camera to ensure that I could record the person's responses during the entire phone conversation. He was making it easier for me to do my job as a filmmaker, but he was also creating another document he could use if the Center forgets to keep its promises.

It was getting dark, but the day's events were not over yet. Yuri decided to follow the tracks of the Lukoil truck and see where they went. We had been driving only for some minutes when Yuri's mobile phone rang and Kolchu informed him that he had spotted a car not far from the camp. Yuri immediately turned the uazik around and speeded towards the camp. Driving through camp, we saw Kolchu waving his hand to the direction the car had disappeared. We followed the car tracks and soon saw a UAZ jeep in the midst of pine trees. It looked like something out of a Russian mafia movie: a black car with dark windows and extra beamers. Yuri blocked its way out of the woods with his uazik, got out and opened the driver's door of the jeep. He waved me to come out of the uazik and asked me to film the face of the driver and the number plate of the car. Like a few hours earlier, Yuri accused the men in the car of violating the license agreement and threatened to inform the general director of Lukoil. The men, who were wearing leather jackets, were apparently some kind of bosses. They remained calm and explained that they just want to fish there. They hinted that Yuri has no reason to complain, because he has probably received material help from local oil people. Yuri left them by saying that they should save their explanations for the general director of Lukoil. ${ }^{28}$

When we were driving back to the camp I brought up again the issue of the possibility of retaliation from the oil people. Yuri said: "The most they could do is to kill me. That's it, there is nothing more they can do". And then he added: "But, please, do not ask these kind of questions in front of Elena Fyodorovna 
[his wife]". After some moments of silence he continued by saying that the oil people would not dare to do anything to him, maybe only when they are drunk. He pronounced it with a serious, inwardly reflecting face while looking straight in front of him. The way he said it sounded like he was trying to persuade himself to believe in his own words.

Yuri told me later that he has caught a couple of trespassers on camera in the past, but he has never done anything with the material. One man begged Yuri on his knees not to inform his superiors and Yuri felt sorry for him; the other brought three tanks of petrol, and as Yuri had a shortage of fuel at the time, he promised not to take the matter any further. This time he seemed to be very determined to make the most out of this video footage. When we got back to the camp he asked me to edit the material into a short video clip in order to show it at the Public Chamber meeting in Khanty-Mansiysk. And when I checked the web page of the Multimedia Center in the beginning of November 2010, I found that the 8 minutes video clip on both trespassers were available for viewing there. But there was no additional information about the issue, no explanation what it was about, the video clip did not even have a title (Yugra State University). ${ }^{29}$

\section{THE FUTURE OF INDIGENOUS AUTOMOBILITY}

Due to good off-road ability and easy maintenance, the uazik cars have proved to be very suitable for the rough road conditions of Western Siberia. It would be probably far-fetched to speak about a "uazik revolution" in Siberia but there is no denying that the car has considerably changed the way of life of many indigenous people in Siberia. Yuri Vella is a good, though slightly exceptional, example how a uazik has been adopted into an indigenous economic and sociocultural system.

In many ways, the extensive car use by indigenous people in Western Siberia has been made possible through the oil companies' presence in the region. The road system that links remote areas around oil wells with major highways, using oil companies facilities to get cars repaired and obtaining illegal fuel from oil workers, all this facilitates a unique way of indigenous car use in Western Siberia. Yuri Vella's "personal automobility" may look very local, but it is a part of that "extraordinarily powerful complex constituted through technical and social interlinkages with other industries, car parts and accessories; petrol refining and distribution; road-building and maintenance; hotels, roadside service areas and motels; car sales and repair workshops..." (Urry 2004: 26, citing Freund 1993). This technical and social interlinking with the outside 
world via car use is constantly changing and increasing. As I have demonstrated in this paper Yuri Vella has to find new ways of exploiting his uazik because the physical and social environment he is acting in, is in constant transformation: if an oil company destroys a bridge, he has to build a new one; if a governor gives away his land, he has to come up with a strategy to maintain his control over it. He is using modern technology to adjust to a changing environment, much like his forefathers adapted to the severe habitat of Western Siberian by sustaining themselves on fishing, hunting and reindeer breeding.

What is the future of this kind of automobility? Seeing Yuri Vella's determination to fight for his way of life, I would say, he will continue spending a big part of his time and energy behind the steering wheel, either taking care of his reindeer, moving between seasonal camps, obtaining fuel and spare parts, or chasing away trespassers from his land. But what about the next generation of indigenous automobilists? Would they do the same? Or would they use cars in a totally different way, maybe even "give in" and retreat from a traditional way of life to villages and towns? Some hints to the answers can be found, if we look at the "car culture" of Yuri's grandsons.

Yuri Vella and other native automobilists living in the forest have been using cars mainly for utilitarian tasks, like changing camp and providing access to modern facilities like shops, post office, ATMs, schools and local authorities. But there seems to be a young generation of native men engaged in traditional subsistence activities that have a different, more hedonistic attitude towards the car. These young men are part of a generation that grew up in the period of the early market economy in post-Socialist Russia. They have been called Generation $\mathrm{P}^{\mathbf{3 0}}$, which stands for the generation of Pepsi Cola, as "they do not avoid the 'fruits' of the global (that is, Euro-American) mass culture and - if possible - are highly attracted to consumer culture" (Ventsel 2009: 9).

Like many of their peers in villages and cities Yuri's grandsons Kolchu and Anton, are fascinated by cars. Yuri gave them his first uazik to use for bringing firewood from the forest and to "make road" from the camp to the nearest oil well when there is lot of snow. The boys took it apart and rebuilt it to their own liking. They had found a set of used truck wheels in the forest, probably left or lost there by a Lukoil driver, and used them to turn the uazik into a "monster truck". The car is really impressive: a minivan on big wheels with extra headlights and the letter $\mathrm{M}$ painted on the front door (that is all they managed to write of "MONSTER 2008", before they got bored).

The boys have even constructed a kind of car repair shop in a shade next to a sauna at the summer camp. They have collected there a few piles of second 
hand spare parts and potentially useful junk that they have found in the forest, and have even set up two old car chairs with a "coffee table" in-between as a rest area of the repair shop. That is the place where they spend most of their spare time when in the camp, either fixing and tuning their Monster truck or just hanging out in the "rest area".

Once I accompanied them with my camera on their daily ride in the nearby forest and it felt like being in a Hollywood teenage movie about car-crazy American youth. The boys had installed a laptop computer along with the set of huge loudspeakers in the car. Anton kept shuffling through the loud pop music, while Kolchu was speeding down the forest road, trying to hit the deepest water and mud pounds on the way. It was kind of a surreal but at the same time revealing experience for me: there I was in the middle of a Siberian forest, with two Nenets boys who for me had always been associated with reindeer and with the sustainable life in the camp, and now realizing that they are part of the global youth culture and addicted to dominant consumer ideology - "culture of excess". I might not have approved of this off-road frenzy in my mind, but I did understand its appeal with my body. Driving there with loud pop songs hammering in my head, brought me back to familiar corporeal sensations from a distant past when I, an adventurer in his early twenties, was in a similar situation in the Arizona desert, chasing a terrified rabbit in a friend's truck while roaring to the music of the Red Hot Chili Peppers.

When we reached an abandoned oil well, Anton got out of the car and took pictures with his mobile phone while Kolchu drove the uazik over steep manmade sand hills. Apparently there is a network of young people who share their taste in monster trucks, and the boys send them photos of their car whenever they re-tune it or do some crazy driving with it. I learned that the site of this oil well has been their playground for many years: even when they come here by car, they like to spend some time climbing up and jumping off the rusty electric posts or throwing high voltage ceramic isolators into the oil well pipes and, by looking at the bubbles of oil in the top end of the pipe, counting the time it reaches the bottom end of the pipe which can be up to 3 $\mathrm{km}$ underground.

Koltchu and Anton did not enter into the world of excessive consumption when they started to do their off-road trips. It has always been there, all around in the form of the oil companies' infrastructure and symbols, and as pollution and trash left behind in the forest by oil workers.

The question for Yuri Vella is whether his grandsons are strong enough to resist the lure of modern consumerism in the long run. Failure to do that would in a local context mean either moving to a village or a town in order to enjoy the comfort offered by "civilized life", or sign off land for the oil compa- 
nies and use their financial support for "easy living" in the forest. Yuri knows that in both cases it often means consuming a lot of alcohol.

Yuri Vella would like to see his grandsons staying in contact with the traditional way of life. But he knows from his personal experience that this is best achieved when the boys first learn more about the outside world and work on their intellect. Therefore, he has been trying hard to persuade them to continue their studies at a university level. So far, he has had very little success. As the boys have always been more interested in tuning their monster truck and playing computer games than reading books, none of them is getting ready to study in the university at the moment. Kolchu is in the army, hoping to get his driving license there. Anton decided not to continue with his studies at the forest school and is now getting his vocational education in the city of Nizhnevartovsk - at the graduation, he will get his driving license and a car mechanic's diploma. It is definitely a wise choice in a local job market as, due to the ever-spreading oil industry, automobility is penetrating even into the remotest corners of the Western Siberian Plain. Whether Anton and Kolchu will return to use their driving and mechanic's skills in the grandfather's forest camp while being engaged actively in reindeer herding or will work instead, for example, at a local Lukoil truck depot, remains to be seen. But, as Yuri Vella admits, the ideal option would be if those two antagonistic worlds could exist in a friendly symbiosis. The indigenous people need and will always use infrastructure built by oil companies in order to maintain their automobilty and to lead a sustainable life in the forest with their reindeer. Hopefully, one day the oil industry will learn to value the indigenous way of life, too.

\section{NOTES}

${ }^{1}$ Confused national and cultural identity is one of the reasons why alcoholism is wide spread among indigenous peoples of Northern Siberia, causing violent deaths and demographic problems (Pika 1993). For updated analyses on population dynamics and changes in the demographic structure of indigenous minorities in Russian North, see Petrov 2008.

${ }^{2}$ Yuri Vella got his first car in exchange for six reindeer from the authorities of Nizhnevartovsk rayon.

${ }^{3}$ UAZ stands for Ulyanovsky Avtomobilny Zavod - Ulyanovsk Car Factory.

${ }^{4}$ I am not referring to those anthropological films where explicit generalizations are presented by a voice-over commentary, or by "talking heads" statements.

${ }^{5}$ In summer of 2009, I did field and film work at Yuri Vella's place with ethnologist and translator Eva Toulouze, who is an old friend of Yuri. Her insights and help have been extremely valuable for writing this paper. 
${ }^{6}$ Yuri Vella got a mobile phone connection in 2000 when Lukoil set up a mobile infrastructure for the neighboring Povkh oil field. Florian Stammler who has written about the "mobile phone revolution" in Western Siberia points out that it happened "when in the capital of the YNAO (Yamal Nenets Autonomous Region) people just got into using pagers" and "it felt almost like from another world to sit in a Moscow apartment and talk to a reindeer herding activist in the taiga. Such an impression led me to my first thoughts about the broad impact of mobile communication in the tundra" (Stammler 2009: 61).

7 Buran is a reliable and unpretentious snowmobile that has been manufactured in Rybinsk factory without major changes for more than 35 years. It was created on the basis of the Bombardier Alpine Ski-Doo 640E of 1967 - this two tracks and one front-ski snowmobile was originally designed for working in the forest, pulling heavy loads (hence, the two tracks), and being easily navigable through branches on the ground (hence, the single front ski). (Stammler 2007: 54) Buran is still one of the most popular snowmobiles in Russia due to its high permeability and simplicity of maintenance.

${ }^{8}$ Florian Stammler argues that, unlike in Fennoskandia, the snowmobile was not the driving force of technological change in Russian Arctic because it was collectively owned, whereas in Fennoscandia it was individually owned. The socio-economic change in Russian northern hunting and herding did not happen on the initiative of the indigenous people themselves. The centralised planners used the mechanised transport as a tool to turn the Soviet North into a giant open-air meat factory and nomads into workers of the 'agro-industrial complex'. (Stammler 2009: 56)

9 For example, French filmmaker and anthropologist Jean Rouch made already in 1950s films, like Les Maîtres Fous (1953) and Moi, Un Noir (1959), to evoke embodied knowledge and sensory experience in his audience (MacDougall 1998; Rouch 2003).

${ }^{10}$ Russia ranks 118th out of 133 countries (alongside with Burundi and Mozambique) in terms of the quality of its highways and it occupies the second place in the world in highway death (25.2 per 100,000 people), second only to Kazakhstan with 30.6 deaths per 100,000 residents. Many believe corruption in road building and in driving schools are to be blamed. (Globe 2010)

${ }^{11}$ Soviet citizens could start buying cars much later than people in the West, only after their elementary consumer needs were met. Even in 1965, for instance, 11 out of every 100 families owned a fridge, 21 in every 100 a washing machine and 24 in every 100 a TV. (Siegelbaum 2009: 16)

${ }^{12}$ Siegelbaum gives a telling example of the extent of such activity in the Soviet Union: at least 75 percent of all gasoline used by private car owners in 1982 was obtained illegally (2009: 24).

${ }^{13}$ In 2006 , for the first time in history, the number of sold foreign cars exceeded that of domestic car in Russia (Yurov 2007).

${ }^{14}$ GAI is an acronym for Gosudarstvennaya Avtomobilnaya Inspektsiya - State Automobile Inspectorate. 
${ }^{15}$ Due to the poor draining and permafrost it is very expensive to build and maintain roads in Western Siberia. For example, it has been estimated that when roads were built in the region in $1960 \mathrm{~s}$, the construction expenses were 1,6-1,7 times higher than in western part of the Soviet Union, and yearly cost of road maintenance averaged about $30 \%$ of the capital investment (Mote 1983: 34).

For Yuri Vella's fictional description of difficulties in road building and on road pollution in the region, see Vella 1999.

${ }^{16}$ Russia's oil industry burns every year around 50 billion cubic meters of natural gas that rises from its oil deposits. This is roughly one third of the world's total, which equals more than five percent of global natural-gas production. (Mrasek 2007)

${ }^{17}$ The term 'bush mechanics' refers to the practice of using materials typically found in the Australian remote areas to make urgent repairs to cars and motorbikes. Bush mechanics use anything they can find, including pieces of wood, grass and rocks to fix anything from flat tires to broken axles. The term is most strongly associated with the Warlpiri aboriginal group living in Yuendumu, in the Western Desert of Australia. They have found "ways around the material deprivations that characterise much of Yuendumu life. They have devised their own ways of being men with wheels, based on an impressive disregard for the orthodoxies of individual car ownership, the economics of the car market, and the professionalisation of automobile repair" (Clarsen 2002).

${ }^{18}$ A joking relationship is an institutionalized form of interaction between certain pairs of people in some societies. It is generally found in situations in which conflict or rivalry is possible but must be avoided.

19 Jean Rouch put the idea of performance at the centre of his filmmaking. He has stated that people, who are being recorded on camera, have reactions that are infinitely more sincere than those they have when they are not recorded (MacDougal 1998: 111).

${ }^{20}$ According to Yuri Vella it corresponds in Russian to the term nuzhnyi chelovek (necessary person) - a conception that was extensively used for operating during the shortage in the Soviet economy. The transcription of Forest Nenets words used in this paper has been made by Kaur Mägi, an Estonian linguist specialising in Samoyed studies.

${ }^{21}$ A driving pole is a 3-4 meter long pole used for driving a reindeer sledge.

${ }^{22}$ According to Yuri that is what had happened to his neighbour's herd: the neigbour had to shoot the reindeers in order to catch them for meat.

${ }^{23}$ Yuri Vella was born in 1948.

24 "The house with stripes" was designed as a school project by a talented high school student from Khanty-Mansiysk as a modern, more comfortable version of the chum to meet the various needs of a reindeer herder.

${ }^{25}$ The area was declared a land reserve, at least partly, because in 1995 Yuri organized a rather "media-friendly" campaign to cancel the auction of the South Vyintoisky oil fields and succeeded in suspending the auctioning for ten years (Novikova 2002; Niglas 2005: 124-128). 
26 The Russian Public Chamber - an advisory panel created in 2005 to serve as a liaison between Russia's civil society and the executive power.

${ }^{27}$ Since July 2007, the Institute of Language, History and Culture of the Peoples of Yugra of Yugorsky State University has been carrying out the Regional Multimedia Center of Clans project with financial support from the UNESCO Bureau in Moscow. The aim of the project is to create a regional multimedia centre for indigenous small people of Khanty-Mansiysk Autonomous Okrug - Yugra, who are keeping a traditional way of life as the basis of their identity maintenance.

Two multimedia points were deployed on the territory of the Surgut region: one for the tribal association of Yugansk Khantys and the other for Yuri Vella's family group. In 2009, the UNESCO Bureau in Moscow additionally furnished these multimedia points with equipment for providing access to the Internet. The objective of the project is: formation of the cultural heritage archives and community mobilization program; creation of an educational site of the technical literacy for communities users; production of multimedia DVDs on traditional rituals and folklore of Khantys and Forest Nenets; creation of Internet portal on basis of web site of two communities in Russian and English, German, Hungarian, Finnish languages; etc. (Regional... 2007)

${ }^{28}$ In a recent telephone conversation with Yuri I learned that his strategy of chasing and filming trespassers has been successful: he has seen only a few cars in the Vatyogan area since autumn 2009; once he caught four men there who left the area immediately after Yuri filmed them and threatened to use the recording if the trespassers did not leave within 30 minutes.

${ }^{29}$ When I checked the link to the webpage a month later, the clip was gone and there was no mention of Yuri Vella. The Internet address consisting of his name contained information about the Scientific Educational Centre for Studying and Protecting the Languages and Cultures of the Indigenous Small-Numbered Peoples of North.

${ }^{30}$ Generation P is a book by modern Russian author Viktor Pelevin (2000). The book describes the life of youth in the Russian Federation - the generation Pepsi Cola who are trying to earn their living by unlawful means in the period of the early market economy. One of the central themes in the novel is consumerism (see also Ventsel 2009).

\section{REFERENCES}

Böhm, Steffen \& Jones, Campbell \& Land, Chris \& Paterson, Matthew 2006. Introduction: Impossibilities of automobility. The Sociological Review. Special Issue: Sociological Review Monograph Series: Against Automobility. Edited by Steffen Böhm, Campbell Jones, Chris Land and Matthew Paterson. Vol. 54, pp. 3-16

Bush Magician ... = Bush Magician: The Battery trick (video clip). Bush Mechanics: The Official Bush Mechanics web-site produced by Warlpiri Association in Yuendumu, available on-line: http://www.bushmechanics.com/home.htm, last accessed 24 Nov 2011.

Clarsen, Georgine 2002. Still Moving: Bush Mechanics in the Central Desert. Australian Humanities Review, No 25, available on-line: 
http://www.australianhumanitiesreview.org/archive/Issue-March-2002/ clarsen.html, last accessed 24 Nov 2011.

Gatejel, Luminita 2009. The Wheels of Desire. Automobility Discourses in the Soviet Union. In: M. Grieger \& U. Gutzmann \& D. Schlinkert (eds.) Towards Mobility: Varieties of Automobilism in East and West. Forschungen Positionen Dokumente: Schriften zur Unternehmensgeschichte von Volkswagen. Band 3, pp. 32-42, available on-line: http://www.volkswagenag.com/vwag/vwcorp/info_center/de/publications/2009/03/towards_mobility.-bin.acq/qual-BinaryStorageItem.Single.File/ VW_FPD03_ES.pdf, last accessed 24 Nov 2011.

Globe, Paul 2010. Corruption Keeping Russian Highways among the Worst in the World, Investigators Say. Window on Eurasia, 8. 03. 2010, available on-line: http://windowoneurasia.blogspot.com/2010/03/window-on-eurasia-corruptionkeeping.html, last accessed 24 Nov 2011.

Grimshaw, Anna 2001. The Ethnographer's Eye: Ways of Seeing in Modern Anthropology. Gambridge: Cambridge University Press.

Edensor, Tim 2004. Automobility and National Identity: Representation, Geography and Driving Practice. Theory, Culture \& Society, Vol. 21, No. 4/5, pp. 101-120.

Helander-Renvall, Elina 2007. Logical Adaptation to Modern Technology - Snowmobile Revolution in Sápmi. The Borderless North. Proceedings of the Fourth NRF Open Meeting, Oulu \& Tornio, Finland and Haparanda \& Luleå, Sweden, pp. 27-33, available on-line: http://www.nrf.is/Publications/The\%20Borderless\%20North/ First\%20Theme_Helander.pdf, last accessed 24 Nov 2011.

Ingold, Tim 1987. The appropriation of Nature: Essays on Human Ecology and Social Relations. Iowa City: University of Iowa Press.

Kiarostami, Abbas 2002. Ten (film). Zeitgeist Films.

Kowal, Donna 2002. Digitizing and Globalizing Indigenous Voices: The Zapatista Movement. In: G. Elmer (ed.) Critical Perspectives on the Internet. Lanham: Rowman \& Littlefield Publishers, pp. 105-126.

MacDougall, David 1998. Transcultural Cinema. Edited by Lucian Taylor. Princeton: Princeton University Press.

MacDougall, David 2005. The Corporeal Image: Film, Ethnography, and the Senses. Edited by Lucian Taylor. Princeton: Princeton University Press.

Mote, Victor 1983. Environmental Constraints to the Economic Development of Siberia (Chapter 3). In: R. G. Jensen \& T. Shabad \& A. W. Wright (eds.) Soviet natural resources in the world economy. Chicago and London: University of Chicago Press, pp. $15-71$.

Mrasek, Volker 2007. Oil Industry Flares $\$ 40$ Billion a Year in Gas. Spiegel Online International. 09.07.2007, available on-line: http://www.spiegel.de/international/ world/0,1518,504511,00.html, last accessed 24 Nov 2011.

Niglas, Liivo 1997. Reindeer in the Nenets Worldview. Pro Ethnologia 5, pp. 7-33, available on-line: http://www.erm.ee/et/Teadus-ja-kogud/Valjaanded/ProEthnologia/Pro-Ethnologia-5, last accessed 24 Nov 2011.

Niglas, Liivo 2003. Yuri Vella's World (film). Documentary Educational Resourses.

Niglas, Liivo \& Toulouze, Eva 2004. Yuri Vella's Worldview as a Tool for Survival: What Filming Reveals Perceptions of Worldview. Pro Ethnologia 17, pp. 95-114, 
available on-line: http://lepo.it.da.ut.ee/ roma1956/images/stories/artiklid/ what\%20filming\%20reveals.pdf, last accessed 24 Nov 2011.

Niglas, Liivo 2005. An Individual's Attempt of Resistance to the Colonial Policy: Yuri Vella's Play with Visual Media. In: A. Leete \& Ü. Valk (eds.) The Northern Peoples and States: Changing Relationships. Studies in folk culture 5. Tartu: Tartu University Press, pp. 112-141.

Novikova, Natalya 2002. Indigenous Rights and Human Rights. 9th International Conference on Hunting and Gathering Societies (9.09. - 13.09.2002), electronic papers and abstracts, University of Edinburgh, http://www.abdn.ac.uk/chags9/ 1novikova.htm, last accessed 19 July 2011.

Pelevin, Viktor 2000. Generation "P”. Moscow: Vargus.

Pelto, Pertti J. 1987. The Snowmobile Revolution. Technology and Social Change in the Arctic. Prospect Heights, Illinois: Waveland Press.

Petrov, Andrey 2008. Lost Generations? Indigenous Population of the Russian North in the Post-Soviet Era. Canadian Studies in Population, Vol. 35, No. 2, pp. 269 290, available on-line: http://www.canpopsoc.org/journal/CSPv35n2p269.pdf, last accessed 24 Nov 2011.

Pika, Alexander 1993. The Spatial-Temporal Dynamic of Violent Death among the Native Peoples of Northern Russia. Arctic Anthropology, Vol. 30, No. 2, pp. 61-76

Pink, Sarah 2006. The Future of Visual Anthropology. London \& New York : Routledge.

Pink, Sarah 2009. Doing Sensory Ethnography. Los Angeles, London, New Delhi, Singpore, Washington DC: SAGE.

Regional Community Multimedia Center 2007. Khanty-Mansiysk: Yugra State University, available on-line: http://unesdoc.unesco.org/images/0015/001592/159200m.pdf, last accessed 24 Nov 2011.

Rouch, Jean 2003. Ciné-Ethnography. Edited by Steven Feld. Minneapolis, London: University of Minnesota Press.

Rouch, Jean 1953. Les Maîtres Fous (film). Films de la Pléiade.

Rouch, Jean 1959. Moi, Un Noir (film). Films de la Pléiade.

Salminen, Tapani 1997. Ecology and ethnic survival among the Nenets. In: H. Shoji \& J. Janhunen (eds.) Northern minority languages: Problems of survival. Senri Ethnological Studies 44. Osaka: National Museum of Ethnology, pp. 93-107

Sheller, Mimi 2004. Automotive Emotions: Feeling the Car. Theory, Culture \& Society, Vol. 21, No. 4/5, pp. 221-242, available on-line: http://www.comp.lancs.ac.uk/ sociology/soc124ms.pdf, last accessed 12 March 2011.

Siegelbaum, Lewis 2009. The Impact of Motorization on Soviet Society after 1945. In: M. Grieger \& U. Gutzmann \& D. Schlinkert (eds.) Towards Mobility: Varieties of Automobilism in East and West. Forschungen Positionen Dokumente: Schriften zur Unternehmensgeschichte von Volkswagen. Band 3, pp. 21-29, available online: http://www.volkswagenag.com/vwag/vwcorp/info_center/de/publications/ 2009/03/towards_mobility.-bin.acq/qual-BinaryStorageItem.Single.File/ VW_FPD03_ES.pdf, last accessed 24 Nov 2011.

Stammler, Florian 2009. Mobile Phone Revolution in the Tundra? Technological Change among Russian Reindeer Nomads. Folklore: Electronic Journal of Folklore, Vol. 41, Generation P in the Tundra: Youth in Siberia. Guest editor Aimar Ventsel, 
pp. 44-78, available on-line: http://www.folklore.ee/folklore/vol41/stammler.pdf, last accessed 24 Nov 2011.

Turner, Terence 1992. Defiant Images: The Kayapo Appropriation of Video Anthropology Today, Vol. 8, No. 6, pp. 5-16.

Urry, John 2004. The "System" of Automobility. Theory, Culture \& Society, Vol. 21, No. $4 / 5$, pp. $25-39$.

Valsiner, Jaan 2007. Personal Culture and Conduct of Value. Journal of Social, Evolutionary, and Cultural Psychology, Vol 1, No. 2, pp. 59-65, available on-line: http:/ /137.140.1.71/jsec/articles/volume1/issue2/JSEC_Valsiner_1-2.pdf, last accessed 24 Nov 2011.

Vella, Yuri 2008. Veterok s ozera: proza $i$ vse, chto napominaet prozu, $7 x 7$. Poligrafist: Khanty-Mansiisk.

Vella, Yuri 1999. Skazka lesnykh nentsev, rasskazannaia v Podmoskovnom lesu. In: O. G. Kornienko \& Iu. K. Aivaseda (comp.) Putem khoziaiki Agana: Sbornik materialov fol'klorno-etnogaficheskoi ekspeditsii, osushchestvlennoi po reke Agan Nizhnevartovskogo raiona v 1996 godu. Priob'e, Nizhnevartovsk, pp. 30-38.

Ventsel, Aimar 2009. Introduction: Generation P in the Tundra. Young People and the Russian North. Folklore: Electronic Journal of Folklore, Vol. 41, Generation P in the Tundra: Youth in Siberia. Guest editor Aimar Ventsel, pp. 9-32, available on-line: http://haldjas.folklore.ee/folklore/vol41/ventsel.pdf, last accessed 22 May 2011.

Verbov, G. 1936. Lesnye nentsy. Sovetskaya Etnografiya 6, pp. 57-70.

Yugra State University. http://www.ugrasu.ru/institutes/yugra/unesko/vella/, last accessed 5 Nov 2010.

Yurov, Alexander 2007. Foreign Cars conquer Russia. Business Day. 30.01.2007, available on-line: http://www.biz-day.com/read/economy/30_jan_07/js8nz-2/ foreign_cars_conquer_russia.htm, last accessed 24 Nov 2011.

Zezina, Maria R. 2009.The Introduction of Motor Vehicles on a Mass Scale in the USSR: from Idea to Implementation. In: M. Grieger \& U. Gutzmann \& D. Schlinkert (eds.) Towards Mobility: Varieties of Automobilism in East and West. Forschungen Positionen Dokumente: Schriften zur Unternehmensgeschichte von Volkswagen. Band 3, pp. 44-54, available on-line: http:// www.volkswagenag.com/vwag/vwcorp/info_center/de/publications/2009/03/ towards_mobility.-bin.acq/qual-BinaryStorageItem.Single.File/ VW_FPD03_ES.pdf, last accessed 24 Nov 2011. 